\title{
SCG2 Gene
}

National Cancer Institute

\section{Source}

National Cancer Institute. SCG2 Gene. NCI Thesaurus. Code C21205.

This gene is involved in intercellular communication and in neuroendocrine secretory

modulation. 